fact, they deliberately select those problems that may lead to some specific solution. Others - historians, teachers, nurses, lawyers, architects, musicians, or whatever - work to equally demanding disciplines, and do not have the luxury of selecting easier options. And they are generally sensible enough to see their work as part of the overall culture. I see no need for any special status for scientific activity.

The more serious point I would make is that this century will be seen by future historians, not as Maddox would like us to view it, but as quite the most barbaric in all history. The two world wars, in which all sides indulged in indiscriminate slaughter, had their origins to some extent in scientific notions - 'survival of the fittest' and genetic purity. Also, there was never the slightest difficulty in recruiting leading scientists to design lethal weapons. Given money and security, scientists, like most other people, will do what is asked of them. There are very few exceptions.

With the knowledge and power we now possess, we need so much more than the abstract, impersonal logic of science. Those who wish to make an alternative religion of Darwinism and reductionism, and encourage belief in the pointlessness of existence, seem to have learnt nothing from the history of this century.

Maddox's final quixotic comment there are still molecular biologists who go to church - reveals much. To those of us not wedded to Darwinian dogma, one might just as well say that there are scientists who still read Plato. We may have cells and DNA that have much in common with the animal world. But in our mentality - which has apparently arisen spontaneously in the last few moments of evolutionary time - we are light years ahead of any other organism. Externally, we have transformed the Earth, creating cities and civilizations; internally, we compose symphonies and formulate predictive mathematical theories. At our best, we think seriously about purpose and meaning, and try to assess the human and social consequences of our work. In this, science provides no guidance, and we each have to find our own path. Religious thought provides one option.

John Evans

81 Cherry Hinton Road,

Cambridge CB1 $4 B S$, UK

\section{Smoke them out}

SIR - Precious research funds are being spent on attempts to identify means of deterring people from smoking. I have a suggestion that might yield economies. In Britain at least, young people, especially women, continue to smoke despite warnings by public health authorities of the dangers. The fault may lie in the messages that adorn cigarette packages and advertising hoardings. "Harm your baby" or "Cause fatal diseases" are anodyne if not challenging to young people. They see smoking as fashionable, romantic, anarchic and exciting: all the supermodels smoke, as do Hugh Grant and Elizabeth Hurley, futures traders and Porsche drivers ${ }^{1}$.

My suggestion is this. Smoking is associated with urinary incontinence in women ${ }^{2,3}$. Moreover, one may assume that the association is causal because transdermal oestrogen is effective in the treatment of mild to moderate stress urinary incontinence in postmenopausal women ${ }^{4}$, and cigarette smoking is anti-oestrogenic ${ }^{5}$.

Cigarette packets should therefore carry the message "Cigarettes cause urinary incontinence". Young people may be half in love with easeful death, but easeful incontinence is a different matter. Once smoking becomes associated with incontinence pads, it will become less fashionable.

\section{William H. James}

Department of Genetics and Biometry, University College London,

Wolfson House,

\section{Stephenson Way,}

London NW1 2HE, UK

1. Coren, G. The Times, 6 December 1995.

2. Tampakoudis, P. et al. Eur. J. obst. Gyn. 63, 27 (1995).

3. Bump, R. C. \& McClish, D. K. Am. J. obstet. Gynec. 167, 1213 (1992).

4. Mäkinen, J. I . et al. Maturitas 22, 233 (1995).

5. Michnovicz, J. J. Steroids 52, 69 (1988). professor, lecturer and a resident of the Swedish university city of Uppsala (pronounced OOP-SA-LA). A consummate classifier, Linné systematized the plant, animal and mineral kingdoms as well as drew up a treatise on the diseases known in his day.

If Linné were alive today, he'd be proud of the vast number of diverse and important scientific fields researchers are involved in. Our job is to help life scientists find solutions by getting involved in their activities. We're Pharmacia Biotech-also from Uppsala.

The diversity of our involvement makes us a little tricky to classify at times. After all, our specialists work with such disciplines as (get
PCR-related areas, cDNA synthesis and cloning, vectors, nucleic acid electrophoresis, hybridization, sequencing, gene expression, restriction enzymes, modifying enzymes, nucleotides, oligonucleotides, polynucleotides, oligonucleotide synthesis, chromatography media, reagents, BioProcess chromatography, electrophoresis systems, electrophoresis media and spectrophotometry. As you can see, our company works with more than just one scientific discipline.

\section{Do you?}

If so, give us a call: I (800) 526-3593 in the USA; +81 334926949 in Japan; or +4618 165000 in Europe and the rest of the world. Or visit us on the Internet: http://www. biotech.pharmacia.se.

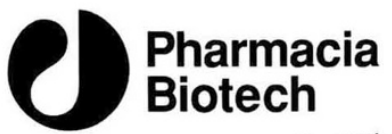

Uppsala. Sweden. (And the rest of the world) 